\section{ECONOMICS}

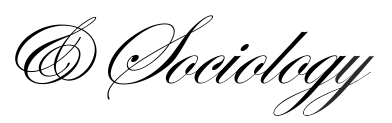

Carvalho, L., Mavlutova, I., Lesinskis, K., \& Dias, R. (2021). Entrepreneurial perceptions of students regarding business professional career: The study on gender differences in Latvia. Economics and Sociology, 14(3), 220-241. doi:10.14254/2071-789X.2021/14-3/12

\title{
ENTREPRENEURIAL PERCEPTIONS OF STUDENTS REGARDING BUSINESS PROFESSIONAL CAREER: THE STUDY ON GENDER DIFFERENCES IN LATVIA
}

Luísa Carvalho

Institute Polytechnic of Setúbal \& CEFAGE - University of Évora, Portugal

E-mail:Luisa.c.carvalbo@esce.ips.pt ORCID 0000-0002-9804-7813

Inese Mavlutova

$B A$ School of Business and

Finance, Riga, Latvia

E-mail:inese.mavlutova@,ba.lv

ORCID 0000-0002-3245-9540

Kristaps Lesinskis

$B A$ School of Business and

Finance, Riga, Latvia

E-mail:kristaps.lesinskis@ba.lv

ORCID 0000-0001-9810-5203

\section{Rui Dias}

Institute Polytechnic of Setúbal \&

CEFAGE - University of Évora,

Portugal

E-mail:rui.dias@esce.ips.pt

ORCID 0000-0002-6138-3098

Received: March, 2021

1st Revision: April, 2021

Accepted: September, 2021

DOI: $10.14254 / 2071-$

789X.2021/14-3/12

JEL Classification: A230, I230
ABSTRACT. This study seeks to investigate the entrepreneurial perceptions among the students regarding their professional careers analyzing macro, micro and entrepreneurial education factors in Latvia, including the analysis of gender differences. The research is based on the analysis of data collected through a survey. The paper uses statistical analysis involving the measures of descriptive statistics (absolute and relative frequencies, means and respective standard deviations) and inferential statistics to examine the differences within an original dataset of 360 young people in Latvia. The results reveal several statistically significant gender differences. This research contributes to enriching literature and also adds value to studies on entrepreneurial perceptions divided by gender. Understanding the factors which shape entrepreneurship education, macrofactors and microfactors affecting young people's decisions and perceptions, education systems and public policies would allow adjusting and designing policies aiming to boost entrepreneurship education and enhance entrepreneurship as a career choice and balance it in a gender context.
Keywords: entrepreneurial education, entrepreneurial intentions, gender, professional career, Latvia 


\section{Introduction}

Globally, entrepreneurship comes as a key to promoting economic development and jobs creation (Audretsch \& Thurik, 2004, 2010). In this context, institutions of higher education promote entrepreneurial education that has become a popular issue during the recent years. Several authors have pointed out the huge increase in entrepreneurship education programs (Kuratko, 2005; Matlay \& Carey 2007; Penaluna, Penaluna \& Jones, 2012), mostly during the last 50 years.

The multidisciplinary nature of entrepreneurial characteristics and personality in literature also means that the terminology is not well standardized, and the research dialogue does not easily lend itself to learning from past research and making incremental progress as a field. The sheer number of journals publishing research studies on entrepreneurial characteristics as well as large differences across them in terms of academic field and quality, also complicates the ability to have a linear, chronologically progressive research dialogue (Kerr et al., 2017).

Fiet (2014) suggested that entrepreneurial education is associated with career choice and personal skills. For example, research finds that entrepreneurial education is positively related to entrepreneurial attitudes and skills. Hattab (2014) argued that entrepreneurship education can develop entrepreneurial intentions through individual attitudes and cognition. Nevertheless, the research focuses on the impact of several other factors that Duffy et al. (2016) classified as macrofactors, such as economic circumstances and public policy, and microfactors, such as personal resources, which are thought to maintain individuals' ability to interact with the environment, take control over situations and play a significant role in changes in their careers.

This topic of choosing a career is particularly relevant in the case of students. According to (Rahmatiah et al., 2019), entrepreneurship patterns in business continuity as a career choice generally do not receive much attention. In particular, young students, when choosing their careers in entrepreneurship, face high uncertainty about what makes entrepreneurship possible (Rahmatiah et al., 2017).

The geography of this research is justified by the lack of such studies carried out in Eastern Europe in general and Latvia in particular. According to (Audretsch \& Thurik, 2004, 2010), a better comprehension of country differences in entrepreneurship is important because entrepreneurship is widely believed to play a key role in economic development. Moreover, this research is especially essential for the countries experiencing systemic transformation from the centrally-planned to a market economy.

Vamvaka et al. (2020), Wilson et al. (2007), Gupta et al. (2009). Shinnar et al. (2012) and several other studies indicated that entrepreneurial intentions vary across genders and that despite the increased participation of females in businesses, higher self-efficacy and level of entrepreneurship education, there are still almost twice as many male entrepreneurs. Current researches reveal that gender has a much higher influence on entrepreneurial intention than age or field of studies (Voda et al., 2019).

The discussion and the results of this research allow finding statistically significant differences between female and male Latvian students' regarding their perceptions towards entrepreneurship as related both to micro and macro factors. The survey was built stemming from the research model developed by the authors based on theoretical literature. Summarizing the answers from the two groups researched, statistical significance in differences of answers' frequency to the same questions was tested. While some of the results confirm the conclusions of other researchers, several other outcomes contradict the findings of previous researches on the same topic. 
The first part of the study discusses the theoretical aspects of entrepreneurial education, gender and professional career choices. The second part presents the research model, empirical study and also provides a discussion of the results along with the concluding remarks.

\section{Literature review}

\subsection{Entrepreneurial education and future career}

Future career opportunities are a major challenge for students, and entrepreneurship can be considered an important choice. The transition from education to careers is seen as a serious challenge for many young people, especially those with low social capital (Blustein et al., 2017). This transition is likely to be more difficult for students facing various macro-level barriers, such as unemployment and others. Several theories and empirical studies have emphasized the importance of two main factors: macro-factors, such as the economic circumstances and public policy, and micro-factors, such as personal resources, which are thought to maintain individuals' ability to interact with their environment, take control of situations and play a significant role in changes in their careers (Duffy et al., 2016).

Atitsogbe et al. (2019) investigated the usefulness of the personal resources of career adaptability and self-efficacy to perceived employability and entrepreneurial intentions and also examined the relationship between perceived employability and entrepreneurial intention: the conclusion was that personal resources may represent a significant contribution to professional performance. Furthermore, Kasler et al. (2017) approved a significant and positive correlation between hope, grit and self-perceived employability. Neneh (2020) examined how entrepreneurial self-efficacy and self-perceived employability affect students' choice of an entrepreneurial career path. Entrepreneurship education must help students acquire entrepreneurial competencies such as autonomy, risk-taking, creativity, cooperation, and the ability to adapt to an uncertain and unpredictable future, but students need to acquire second-order competencies (or meta-competencies) (Toutain and Alain, 2017).

Rossier (2015) argued that career adaptability is an essential resource along with emotion regulation skills or self-efficacy explored using social cognitive career theory. Rudolph et al. (2017) referred that career adaptability is significantly related to a number of personality, career, and work-related factors, which can be divided into four categories, such as adaptivity, adapting response, adaptation result, and socio-demographic variables.

Savickas and Porfeli (2012) created a measure to assess career adaptability resources, namely Career Adapt-Abilities Scale. Lim et al. (2016), Lent et al. (2017) believe that selfefficacy is a mediator that influences career development outcomes: interest development, choice making, and performance achievement; the social cognitive model of career selfmanagement emphasized the importance of personal resources such as self-efficacy in a number of career outcomes. Recently, Vamvaka et al. (2020) suggested that career patterns vary across genders and that despite the increased participation of women in the enterprise sector, there are still almost twice as many male entrepreneurs.

According to several contributions, self-efficacy plays a significant role in the entrepreneurial behavior (Bandura, 1977). Expectations of personal efficacy derive from four main sources: performance accomplishments (empowerment), vicarious experience (vicarious learning, influence of role models), verbal persuasion (influence of the coach), and emotive sources (expression of a positive /negative emotional feedback, emotional stimulation). Sinapi et al. (2015) assume that business creation tools and entrepreneurial mindset result, among various perspectives, in the development of perceived self-efficacy regarding the ability to 
conduct an entrepreneurial project. Some authors underline that most of entrepreneurship studies present comparative analysis of factors regarding students' intentions to perform an entrepreneurial activity (Iakovleva et al., 2011)

In a regional context, several researchers suggest that students from developing (in transition countries) economies are more likely to relate their future careers to entrepreneurship and are more positive towards entrepreneurship than students from industrialized European countries, even though motivators for employment/self-employment are similar across the samples (Davey et al., 2011).

\subsection{Theoretical models of entrepreneurship education}

Theoretical models that have dominated understanding and possibly predicting entrepreneurship in recent decades are intention-based models of entrepreneurial behavior (Baumol, 1993; Gaglio \& Katz, 2001) led by Ajzen (Ajzen, 1985; Ajzen, 1991). Theory of Planned Behavior is a dominating model for understanding, predicting, and changing individual social behavior (Ajzen, 2011). This theory considers entrepreneurship as a planned, volitionally controlled behavior that is inherently intentional rather than instinctive, in which individuals develop entrepreneurial intentions over time before initiating actions to create a new venture and making the entry decision. (Vamvaka et al., 2020)

The Theory of Planned Behavior consists of the following dimensions (Ajzen, 1987): attitude toward the behavior (ATB), subjective norms (SN), and perceived behavioral control (PBC):

1. Attitudes towards behavior is a reflection of the individual's appraisal of the behavior. It indicates the degree of how favorably or unfavorably an individual evaluates a specific behavior, and it explains the half of variance in intentions.

2. Subjective norms portray the degree of social components (family, friends, femininity and masculinity, peers and society in general) that expect or pressure the individual to become an entrepreneur.

3. Perceived behavior control or self-efficacy is related to the level at which an individual feels able to behave in an entrepreneurial manner. It has a direct effect on behavior, as individuals can balance possible constraints with their actual control of overcoming those constraints (Ajzen, 1987).

Regarding the intentions to become an entrepreneur, the recent literature review allows an aggregation of studies related to the categories of Theory of Planned Behavior and identify important constructs to consider in empirical studies to assess entrepreneurial perceptions (Carvalho et al., 2015). Table 1 provides a synthesis of the Theory of Planned Behavior and Entrepreneurial Perceptions.

Perceptions about entrepreneurship can be assessed through entrepreneurship education. Keller and Kozlinska (2019) proposed a systematic literature review on entrepreneurial affect and emotions, their importance in entrepreneurship education, and created a framework.

Cheung (2008) suggested that the sooner values and entrepreneurial thinking in young people are stimulated, the more effective the results will be. The task of entrepreneurship education is to foster students' abilities, such as the capacity to recognize opportunities, as well as knowledge, skills and attitudes to develop these opportunities (Jones and English, 2004). While some personality traits are fixed, Rauch (2014) investigated how self-efficacy and achievement motivation can be influenced with relatively simple entrepreneurship education methods when personality traits are defined. However, there is an opinion that mostly entrepreneurship education focuses on helping students to understand the phenomenon and doesn't prepare them for entrepreneurial activities (Pittaway and Edwards, 2012). 
Table 1. Dimensions of the theory of planned behavior and entrepreneurial perceptions

\begin{tabular}{|c|c|c|}
\hline Attitudes towards behavior & Subjective norms & Perceived behavior control \\
\hline $\begin{array}{l}\text { Perception of barriers: Entry or start- } \\
\text { up barriers, including lack of } \\
\text { knowledge, start-up capital } \\
\text { Barriers: Too risky activities, lack of } \\
\text { entrepreneurial abilities, unfavorable } \\
\text { economic situation, fear of failure, } \\
\text { irregular income, lack of } \\
\text { management and accountancy skills } \\
\text { Desirability: Attractiveness for the } \\
\text { person to create a new business } \\
\text { Individual-level entrepreneurial } \\
\text { intention: Access to know-how, } \\
\text { access to know-who, access to } \\
\text { material support, need for } \\
\text { achievement, need for independence, } \\
\text { risk-taking propensity, work } \\
\text { experience, opportunity perception }\end{array}$ & $\begin{array}{l}\text { Culture: Country } \\
\text { individualism/collectivism, } \\
\text { power distance, } \\
\text { uncertainty avoidance, } \\
\text { Gender characteristics: } \\
\text { femininity/masculinity } \\
\text { Relational support: Family } \\
\text { background, friends' } \\
\text { support } \\
\text { Institutional environment: } \\
\text { Perception of feasibility, } \\
\text { the factors that influence } \\
\text { and make entrepreneurship } \\
\text { more difficult, } \\
\text { entrepreneur's image }\end{array}$ & $\begin{array}{l}\text { Entrepreneurial disposition: Self-efficacy } \\
\text { Perception of motives: Individual belief, } \\
\text { confidence in the belief, intention to act } \\
\text { Motives: Opportunity to implement ideas, } \\
\text { creating something new, personal } \\
\text { independence, ambition to become a } \\
\text { manager, financial independence, } \\
\text { improvement of life quality, creation of } \\
\text { work places, managing the staff, more } \\
\text { leisure time, opportunity to earn money, } \\
\text { acquiring of a higher social status, } \\
\text { difficulties finding the most suitable job, } \\
\text { family traditions } \\
\text { Personality traits: Self-efficacy, } \\
\text { proactivity, risk taking } \\
\text { Feasibility: perception regarding one's } \\
\text { own capacity to become an entrepreneur }\end{array}$ \\
\hline
\end{tabular}

Source: Carvalho et al., (2015), adapted

Kerr et al. (2017) developed a research on personality traits and created a classification of personality characteristics named the Big Five: need for achievement (motivation), locus of control, self-efficacy/proactivity, innovativeness, stress/uncertainty tolerance and need for autonomy. The Big Five model is a multidimensional approach towards defining personality through measuring openness, conscientiousness, extraversion, agreeableness, and neuroticism created by Tupes and Christal $(1961,1992)$ and Norman (1963). Since the 1980s, it has been considered as the dominant model of personality traits, and it was found that the Big Five traits affect entrepreneurs' career choice (Rauch, 2014). The Big Five model dimensions are:

- Openness to experience: describes the breadth, depth, originality, and complexity of an individual's mental and experimental life

- Conscientiousness: describes socially prescribed impulse control that facilitates taskand goal-orientated behavior

- Extraversion: implies an energetic approach towards the social and material world and includes traits such as sociability, activity, assertiveness, and positive emotionality

- Agreeableness: contrasts a prosocial and communal orientation toward others with antagonism, and includes traits such as altruism, tender-mindedness, trust, and modesty

- Neuroticism: contrasts emotional stability and even-temperedness with negative emotionality, such as feeling anxious, nervous, sad, and tense.

Entrepreneurs may need success because building a business from scratch shows a person's individual abilities in ways that are often difficult to reconcile when working in a system where responsibilities are spread. A person with an internal locus of control understands that their own decisions control their lives, while people with an external locus of control believe that the real factors of control are chance, fate, or environmental traits that they cannot control. Individuals with an internal control locus believe that they can influence outcomes through their ability, effort, or skill, rather than the external forces that control those outcomes (Kerr et al., 2017).

Entrepreneurial self-efficacy is defined as a composite of self-efficacy towards five tasks: innovation, risk-taking, marketing, management and financial control. When surveying students in three business study programs, it was found that entrepreneurship students have a higher entrepreneurial self-efficacy average in marketing, management and financial control 
than did organizational psychology and management students (Chen et al., 1998; Chatterji et al., 2014; Yen and Lin, 2020).

Åstebro et al. (2014) summarize the utility model of standard expected risk selection and define how entrepreneurs are distinguished from others by their willingness to perceive and act as much as possible, despite uncertainty and risk.

In addition to the personal characteristics of what makes an individual an entrepreneur, there are other important factors that motivate students to establish a new business. Personality characteristics correlate with each other, while also impacted and shaped by environmental forces. Researchers in all disciplines frequently describe how personality factors such as gender and education interact with or are moderated by other individual traits and external conditions (e.g., industry dynamics, city traits) (Kerr et al., 2017). Attributes of the environment, such as perception of the State or political and legislative climate in which the young person finds him or herself immersed, are vitally important (Díez-Echavarría et al., 2020).

Entrepreneurs tend to be optimistic and overconfident, and at the same time, these traits may be deleterious for entrepreneurial performance (Bengtsson \& Ekeblom, 2014). Hurst and Pugsley (2016) divided the original motivations into categories: non-pecuniary reasons, to generate income, to accomplish a good business idea, lack of employment options, and others. The majority of small businesses do not intend to innovate or expand their operations, and non-pecuniary motivations are the most frequent driver of new venture creation. Eyel et al. (2020) believe the individual values about obtaining the achievement and power are influential on all entrepreneurial tendency factors.

The external environment, particularly the regional geography, is another issue studied. Some researches point out this geographic comparison, such as the differences in the promotion of sustainability and the development of a sustainable mindset of students, and differences between sustainable mindset of students from Central and Eastern Europe (Ploum et al., 2018; Fox et al., 2019, Çera et al., 2019; Adomssen et al., 2014). Despite a number of comparative studies of European regions, such as an empirical comparative study of universities in Northern and Southern Europe (Markuerkiaga et al., 2016; Eizaguirre et al., 2020; Keller, 2017), many authors emphasize that more researches from different regions of Europe are needed (Adomssen et al., 2014), in particular in Eastern European countries.

\subsection{Entrepreneurship education and gender}

One of the entrepreneurship research areas in this research is that of gender differences in entrepreneurial perceptions. Concerning the gender, some studies suggested that there is a perception of entrepreneurship as something more suited for males who are widely perceived as being more predisposed to engage in entrepreneurial activity than women and possessing qualities or characteristics such as independence, aggressiveness, autonomy and courage, typically considered essential for entrepreneurship (Shirokova et al., 2016; Vamvaka et al., 2020).

Wilson et al. (2007), Gupta et al. (2009), Shinnar et al. (2012) and various other researches based on the Hofstede's Cultural Dimensions Theory (Hofstede, 1998) have proved that career patterns vary from country to country for different genders, that, despite the growing participation of females in the business, there are still fewer female than male entrepreneurs, and that males have a more positive attitude towards entrepreneurship and higher entrepreneurial intentions. It seems that business is associated with male gender stereotypes, however Liñán and Fayolle (2015) believe the level of female self-efficacy is higher and the impact of entrepreneurship education on entrepreneurial intentions is stronger. On the other hand, other studies confirm that males exhibit a more positive attitude towards 
entrepreneurship and a greater intention of starting a business (Roxas et al., 2008). CameloOrdaz et al. (2016) designed the research with the main purpose of analyzing the influence of perceptual factors - entrepreneurial self-efficacy, the ability to recognize opportunities, and fear of failure - on the relationship between gender and entrepreneurial intention and found out that the fear of failure is one the most important obstacle perceived by female students for starting a business. These findings follow a line of previous research that has highlighted the importance of business self-efficacy in explaining higher entrepreneurial intentions among males.

Haus et al. (2013) concluded that females transform their entrepreneurial intentions into action less frequently than males due to the fact that females tend to perceive various obstacles to entrepreneurship that are more tangible. In 2019, The Global Entrepreneurship Monitor (GEM) examined entrepreneurial activity in 50 countries. The results indicate that, although globally the female to male entrepreneurship rate has increased in recent years, the number of female entrepreneurs is generally much lower than the number of male entrepreneurs (GEM, 2020). Moreover, OECD research has found that in the EU an average of $9.9 \%$ working females are self-employed, while the respective number of males is $17.5 \%$. Moreover, self-employed females are less likely than males to have employees and tend to work on average more hours per week (OECD, 2017).

The analysis conducted by Voda et al. (2019) revealed that gender also had a positive and significant effect, indicating that females are less active in the process of launching startups; at the same time, age and faculty type do not influence significantly the entrepreneurial intention. This means that gender has a much higher effect on entrepreneurial intention than age and faculty type.

On the other hand, several studies show that females need financial management knowledge more than males (Al-Bahrani et al., 2020). They are less exposed to risk and avoid borrowing, equity crowdfunding and raising angel or venture capital, which doesn't allow them to start a business (Malaga et al., 2019).

Contemporary research confirms that in the digital age, females are not strong in ICT and related industries, launching fintech start-ups, despite years of education in ICT and related subjects at the universities. The use of ICT and STEM, especially in start-ups, means educating females as technology professionals and entrepreneurs in a world of growing demand for ICT applications and services is very important (Ashcraft et al., 2016; Kamberidou \& Pascall, 2019; Kamberidou, 2020). Other researchers also emphasize the importance of using information and communications technology in new ventures nowadays (Bandera et al., 2018).

Gender differences in entrepreneurship and characteristics of female entrepreneurs in Latvia have not been fully studied, only a few studies on female executives have emerged in recent years (Dzene \& Sennikova, 2020).

\subsection{Latvia in a context of Eastern European entrepreneurship}

A better comprehension about the country differences in entrepreneurship is important because entrepreneurship is widely believed to play a key role in economic development (Audretsch and Thurik, 2004, 2010). This analysis is especially important in the countries experiencing systemic transformation from the centrally-planned to a market economy system. Latvia fell under Soviet domination, which lasted until 1990. This implied that for almost 50 years private business ownership was banned or scarcely tolerated as a marginal, and economy was dominating by state-owned sector. In this context, entrepreneurship is an emergent topic just exploited after the end of the communist regime. Zinovyev (1986) mentioned the "homo sovieticus" mindset developed by several generations of population 
living under communism, that could reflect the lack of individual initiative, overreliance on the state, and passive, obedient acceptance of the rules imposed by the government authorities. Therefore, it is important to understand whether the new generations still possess some limitations in respect to the entrepreneurial mindset.

Moreover, Eastern European countries reveal differences, and some countries are more studied than others. Latvia is one of the understudied countries in this European region.

The case of Latvian entrepreneurship is worth attention and research. There are several reasons for that. From year to year, according to Global Entrepreneurship Monitor adult population studies, Latvia ranks first or one of the first in terms of entrepreneurial activity. In 2019, Latvia had (GEM, 2019) the highest Total early-stage Entrepreneurial Activity (TEA) rate and the 2nd highest Established Business Ownership (EBO) rate among the EU countries that were included in the sample. The numbers were $15.4 \%$ and $12.9 \%$ in adult (18-64) population respectively. In the same study, Latvia ranks first in TEA rate for females, scoring $11.3 \%$ of all adult females.

Moreover, Latvia also has the highest entrepreneurial activity TEA indicator (20\%) among the researched EU countries in the age group of 18-24 (GEM, 2019). But it is unclear whether this high number is related to entrepreneurship education practices in the country or to some other reasons. To make things more complicated and to provide even more room for studies, it should be noted that in the same GEM survey Latvia has the most pessimistic answers to the question whether "There are good opportunities to start a new business in my area"- only $35.6 \%$ (GEM, 2019) of adults answered positively to this question, which is the lowest number among the EU countries researched.

There has been some research devoted to business education in general and entrepreneurship education in particular, and scientific literature includes sources originating from Latvia. Nikitina and Lapina (2019) found out that very high intensity of establishing small and medium-sized enterprises (SMEs) in Latvia takes place because various measures for the establishment and support of micro-enterprises have been implemented. The same authors identified that the skills acquired by managers were mostly experience-based competencies that dominate over the rest. Salite (2015) analyzed recent trends affecting the development and management of entrepreneurship education, as well as the impact of European Union policies on the transformation of entrepreneurship education and emphasized the need to reorient education towards sustainability.

At the same time, studies underline considerably declining activity in starting entrepreneurship, as well as students' entrepreneurial intentions to set up their own business and to associate their future careers with entrepreneurship. Bikse, Lusena-Ezera and Rivza (2016) analyzed performance trends in young entrepreneurs' capacity. Nikitina and Lapina (2017) investigated Latvian students' entrepreneurial attitudes to become self-employed. The results of the survey conducted indicate that, in recent years, students have had insufficient information and knowledge about entrepreneurship promotion measures and labor market. Mavlutova, Lesinskis, Liogys and Hermanis (2020) underline the growing importance of modern teaching techniques for entrepreneurship education using software.

Bikse, Riemere, Rivza (2014) concluded in their study that there is a need to improve the teaching and training of entrepreneurship in Latvia and to implement targeted career education measures. Kozlinska (2016) believes that Latvia is slightly lagging behind Estonia in entrepreneurship education as it has not been actively lobbied in Latvian political circles and is still sometimes treated as part of management education.

But there is still a considerable gap in entrepreneurship education studies, including aspects of entrepreneurial aspirations, gender differences, motivation, skills and efficiency of teaching methods. 


\section{Methodological approach}

\subsection{Research model}

Graph 1 systematizes the literature review and provides a design model for the empirical study. It summarizes the set of macro-factors that are environment enablers or disablers of entrepreneurial intention.

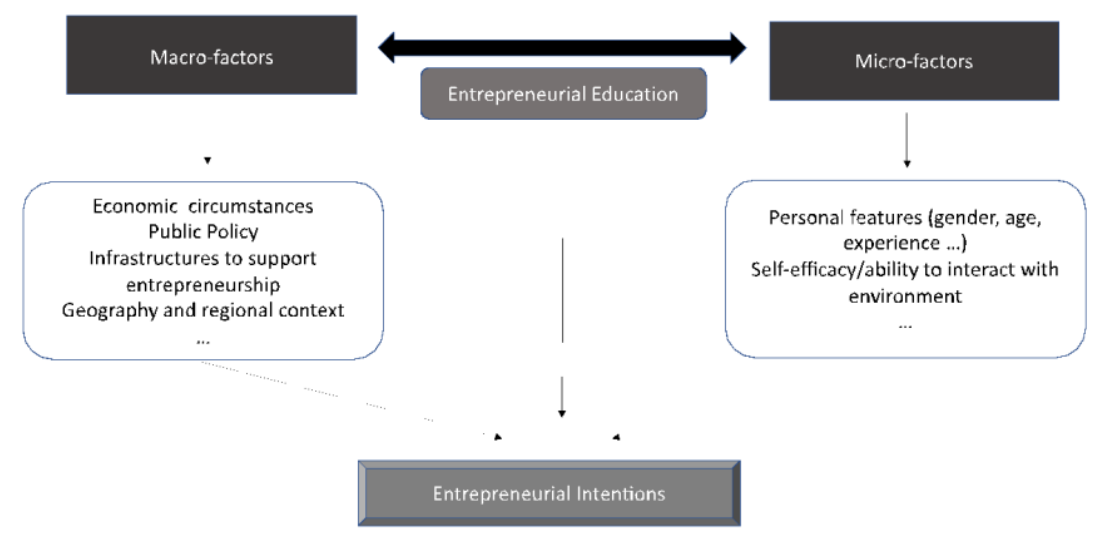

Graph 1. Research Model supported in the Literature Review Source: Authors

These aspects can influence the individual decisions on entrepreneurship as a professional career. They also compile the set of micro-factors, which are more intrinsic to each individual and that also influence their perception about entrepreneurship as a future professional choice, whether positively or negatively. In the middle, entrepreneurship education acts as an enabler of developing and enhancing some personal traits and giving some tools essential to run a business. These factors, including the differences between genders, can interact and promote (or limit) the entrepreneurial intentions and choice for being an entrepreneur in professional life.

\subsection{Sample and statistical considerations}

This exploratory study collected a convenience sample. It consists of a total of 360 680-respondents. In terms of gender, 59.7\% are female and $40.3 \%$ are male. Proportion of male and female in a survey represents the gender structure of Latvian students. The sample was collected in 2018 and 2019 using a digital questionnaire based on the literature review above. Table 2 shows the main characteristics of the sample.

The statistical analysis involved measures of descriptive statistics (absolute and relative frequencies, means and respective standard deviations) and inferential statistics. The level of significance for rejecting the null hypothesis was fixed at $\alpha \leq .05$. The Chi-square test and the Fisher test were used. The Chi-square assumption that there should be no more than $20 \%$ of cells with expected frequencies below 5 was analyzed. In situations where this assumption was not satisfied, the Chi-square test by Monte Carlo simulation was used. The differences were analyzed with the support of standardized adjusted residuals. 
Table 2. Sociodemographic characteristics $(\mathrm{N}=360)$

\begin{tabular}{lcc}
\hline & $\mathrm{N}$ & $\%$ \\
\hline Gender & & \\
\hline Male & 215 & 59.7 \\
\hline Female & 145 & 40.3 \\
\hline Age & & \\
\hline 20 years or less & 105 & 29.2 \\
\hline $21-24$ & 169 & 46.9 \\
\hline 25 years or more & 86 & 23.9 \\
\hline Level of studies & & \\
\hline Bachelor $1^{\text {st }}$ & 98 & 27.2 \\
\hline Bachelor $2^{\text {nd }}$ & 76 & 21.1 \\
\hline Bachelor $3^{\text {rd }}$ & 93 & 25.8 \\
\hline Bachelor $4^{\text {th }}$ & 36 & 10.0 \\
\hline Master $1^{\text {st }}$ & 36 & 10.0 \\
\hline Master $2^{\text {nd }}$ & 21 & 5.8 \\
\hline
\end{tabular}

Source: Authors' calculations

Most of the respondents are up to 24 years old (76.1\%) and most of them study on the Bachelor level. The representation of master students is small (15.8\%).

\section{Conducting research and results}

The data collected allows to understand the profile of the young respondents concerning their expectation about the future career plans. Table 3 compares males with females. Answers to the first question regarding professional career plans ("In my professional life I see myself as") reveal that the majority of females $(53.5 \%)$ see themselves working for private or public organization as a specialist or manager, while just $20.9 \%$ desire to develop or manage their own business. However, the results for males are inverse- $46.2 \%$ desire developing and managing their own business. With a $\chi^{2}(2)=28.455, \mathrm{p}=.001$.

Table 3. Future career plans by gender

\begin{tabular}{lccc}
\hline & Female & Male & Total \\
\hline Developing and managing my own business & $20.9 \%$ & $46.2 \%$ & $31.1 \%$ \\
\hline I have not decided yet & $25.6 \%$ & $23.4 \%$ & $24.7 \%$ \\
\hline $\begin{array}{l}\text { Working for private or public organization as a } \\
\text { specialist or manager }\end{array}$ & $53.5 \%$ & $30.3 \%$ & $44.2 \%$ \\
\hline$\quad$ Total & $100.0 \%$ & $100.0 \%$ & $100.0 \%$ \\
\hline
\end{tabular}

Source: Authors' calculations

Regarding the perceptions about the skills required to start a business, $52.5 \%$ of Latvian students consider they have some relevant skills to start a business; however, only $6.7 \%$ are fully confident about the all necessary skills. The differences between genders are smaller, however males seem more confident in self-evaluation about their skills.

The most notable difference between genders can be found in answer where respondents assume full confidence for having all the set of skills necessary to start a business. Only $3.7 \%$ of female have chosen this answer while the proportion of such responses among male is $11 \%$. 
Table 4. Self-evaluation about the skills required to start a business by gender

\begin{tabular}{lccc}
\hline & Female & Male & Total \\
\hline I do not have them at all & $5.6 \%$ & $2.8 \%$ & $4.4 \%$ \\
\hline I have everything to start & $3.7 \%$ & $11.0 \%$ & $6.7 \%$ \\
\hline I have most of them & $16.7 \%$ & $22.8 \%$ & $19.2 \%$ \\
\hline I have some, but not enough & $54.0 \%$ & $50.3 \%$ & $52.5 \%$ \\
\hline I have very few & $20.0 \%$ & $13.1 \%$ & $17.2 \%$ \\
\hline Total & $100.0 \%$ & $100.0 \%$ & $100.0 \%$ \\
\hline
\end{tabular}

Source: Authors' calculations

Table 5 contains an analysis of macro and micro factors that influence entrepreneurial intentions of Latvian students and characterizes their differences for male and female respondents.

Looking at respondents' views on why people choose entrepreneurship as a career, it can be seen that the responses of both genders are very similar. Both male and female consider two reasons to be the most important- desire for independence ( $74.4 \%$ of female and $73.8 \%$ of male) and profit, power and status (54.9\% of female and $55.2 \%$ of male).

Leadership, charisma and communication skills are believed to be the most important qualities and preconditions needed to become a successful entrepreneur both by female $(67.4 \%)$ and male $(59.3 \%)$ respondents. Discipline and ability to work independently is believed to be highly important too. Both in the section on motivation, and on qualities and preconditions needed, answers by male and female are very similar.

The gender difference in answers arrives in section on most important factors discouraging to start a business. Even though both genders equally believe lack of experience and business network and lack of necessary financial resources to be the most discouraging factors (although females assess the role of financially starting a business higher), there is also disagreement on some other factors. For example, female attach important role $(26.5 \%)$ for the factor "stress, possible impact on my health" while only $15.2 \%$ of male believe it is an important factor to discourage starting a business. Inappropriate business environment is considered to be an insignificant factor among female (10.7\%), while male respondents attach bigger importance to this factor (17.2\%).

Checking potential of business ideas, finding financial sources and mentoring and consulting are equally considered to be the most appreciated assistance forms for starting a business both by male and female. Still, it should be noted that checking potential of business ideas is more important among female $(76.1 \%)$ than male $(62.4 \%)$, meaning that males are more confident about their business ideas.

There are gender differences on what skills should be improved through education to start a business. Female are more frequently (49.8\%) looking for financial management skills improvement, while male (34.5\%) attach lower importance to this education. On the contrary, the biggest importance among male (61.4\%) in respect to education is attached to acquisition of specific professional skills related to industry specifics, while female (47\%) scored lower importance to this factor. Both genders believe that development of business ideas should be extensively trained through educational activities.

Professional evaluation of soundness and perspective of business ideas, existence of financial support programs and access to mentors and business consultants stand out as the most important types of external support required to start and run a business idea for both male and female. Existence of financial support programs is highly expected (71.2\%) among female. 
Table 5. Perceptions, micro-factors and macro-factors influencing entrepreneurial intentions by gender

\begin{tabular}{|c|c|c|c|}
\hline & Female & Male & Sig. \\
\hline \multicolumn{4}{|l|}{ MICRO-FACTORS } \\
\hline \multicolumn{4}{|c|}{ Most important reasons why people pursue entrepreneurship as a career choice } \\
\hline Desire for independence (being your own boss) & $74.4 \%$ & $73.8 \%$ & 903 \\
\hline Profit, power and status & $54.9 \%$ & $55.2 \%$ & 1.000 \\
\hline Creating and making a better world & $24.2 \%$ & $23.4 \%$ & .900 \\
\hline Dissatisfaction from being employed by others & $27.0 \%$ & $29.7 \%$ & .633 \\
\hline Personal development & $19.1 \%$ & $17.9 \%$ & .890 \\
\hline \multicolumn{4}{|c|}{ Qualities and preconditions needed to become a successful entrepreneur } \\
\hline Discipline, ability to work independently & $60.5 \%$ & $58.6 \%$ & .743 \\
\hline Optimism and confidence & $34.0 \%$ & $34.5 \%$ & 1.000 \\
\hline Ambitiousness and purposefulness & $51.6 \%$ & $44.8 \%$ & .237 \\
\hline Creativity, capability to innovate, vision & $58.1 \%$ & $55.9 \%$ & .745 \\
\hline Readiness to risk & $54.0 \%$ & $57.9 \%$ & .517 \\
\hline Specific knowledge in the field, industry & $35.3 \%$ & $35.9 \%$ & 1.000 \\
\hline Formal education degree & $5.1 \%$ & $2.1 \%$ & .173 \\
\hline Business network & $23.7 \%$ & $35.2 \%$ & $.023 *$ \\
\hline Financial or material resources & $38.1 \%$ & $33.1 \%$ & .371 \\
\hline Business experience & $11.2 \%$ & $15.2 \%$ & .265 \\
\hline Leadership, charisma and communication skills & $67.4 \%$ & $59.3 \%$ & .118 \\
\hline Persistence to stress and good health & $21.4 \%$ & $21.4 \%$ & 1.000 \\
\hline Flexibility, readiness for adaptation & $39.1 \%$ & $46.2 \%$ & .192 \\
\hline \multicolumn{4}{|c|}{ Most important factors discouraging to start a business } \\
\hline Fear of failure & $48.8 \%$ & $49.7 \%$ & .915 \\
\hline Stress, possible impact on my health & $26.5 \%$ & $15.2 \%$ & $.013 *$ \\
\hline Lack of knowledge and skills & $48.8 \%$ & $57.9 \%$ & .107 \\
\hline Lack of experience and business network & $60.5 \%$ & $58.6 \%$ & .743 \\
\hline Lack of necessary financial resources & $68.4 \%$ & $62.8 \%$ & .307 \\
\hline Inappropriate business environment & $10.7 \%$ & $17.2 \%$ & .083 \\
\hline Lack of government support & $20.5 \%$ & $17.9 \%$ & .589 \\
\hline Personal and family preconditions & $15.8 \%$ & $20.7 \%$ & .262 \\
\hline \multicolumn{4}{|l|}{ MACRO-FACTORS } \\
\hline \multicolumn{4}{|c|}{ External support asked to start a business } \\
\hline Checking potential of my business ideas & $76.1 \%$ & $62.4 \%$ & .083 \\
\hline Finding financial sources & $73.2 \%$ & $64.7 \%$ & .300 \\
\hline Business training & $31.0 \%$ & $28.2 \%$ & .727 \\
\hline Mentoring and consulting & $60.6 \%$ & $58.8 \%$ & .871 \\
\hline Infrastructure & $23.9 \%$ & $35.3 \%$ & .161 \\
\hline Informational support & $38.0 \%$ & $50.6 \%$ & .146 \\
\hline \multicolumn{4}{|c|}{ Most problematic factors for doing a business in a country } \\
\hline Inefficient government bureaucracy & $61.9 \%$ & $57.2 \%$ & .383 \\
\hline Tax rates and regulation & $75.8 \%$ & $69.7 \%$ & .225 \\
\hline Government and policy instability & $58.1 \%$ & $50.3 \%$ & .161 \\
\hline Inappropriately educated workforce & $16.3 \%$ & $25.5 \%$ & $.043^{*}$ \\
\hline Access to funding & $55.8 \%$ & $45.5 \%$ & .067 \\
\hline Inadequate infrastructure and facilities & $24.2 \%$ & $20.0 \%$ & .371 \\
\hline
\end{tabular}




\begin{tabular}{|c|c|c|c|}
\hline Corruption & $48.8 \%$ & $58.6 \%$ & .085 \\
\hline Insufficient capacity to innovate & $25.1 \%$ & $22.1 \%$ & .531 \\
\hline Lack of ethic in national labor force & $29.3 \%$ & $40.7 \%$ & $.031 *$ \\
\hline Crime & $4.7 \%$ & $9.0 \%$ & .124 \\
\hline \multicolumn{4}{|c|}{ MACRO FACTORS THAT COULD BE ENABLED BY ENTREPREURIAL EDUCATION } \\
\hline \multicolumn{4}{|c|}{ Skills needed to start a business } \\
\hline Development of business ideas & $61.9 \%$ & $57.2 \%$ & .383 \\
\hline Assessment of business potential of business ideas & $42.8 \%$ & $43.4 \%$ & .914 \\
\hline Communication, leadership and general management skills & $54.9 \%$ & $47.6 \%$ & .197 \\
\hline Sales and marketing skills & $43.3 \%$ & $55.2 \%$ & $.031 *$ \\
\hline Financial management skills & $49.8 \%$ & $34.5 \%$ & $.005 * *$ \\
\hline Specific professional skills related to industry specifics & $47.0 \%$ & $61.4 \%$ & $.010^{*}$ \\
\hline \multicolumn{4}{|c|}{ External support required to start and run a business idea } \\
\hline $\begin{array}{l}\text { Professional evaluation of soundness and perspective of } \\
\text { business idea }\end{array}$ & $59.2 \%$ & $60.0 \%$ & 1.000 \\
\hline Existence of financial support programs & $71.2 \%$ & $59.0 \%$ & .070 \\
\hline Access to mentors and business consultants & $63.2 \%$ & $70.5 \%$ & .264 \\
\hline Access to appropriate infrastructure & $35.2 \%$ & $45.7 \%$ & .108 \\
\hline Access to business training & $34.4 \%$ & $30.5 \%$ & .574 \\
\hline Support from family, relatives and friends & $36.0 \%$ & $33.3 \%$ & .680 \\
\hline
\end{tabular}

Source: Authors' calculations

$* p<.05 * * p<.01 * * * p<.001$

Table 6 shows the comparative results by gender through the use of the statistically significant variables, and also provides a linkage with literature review. The signal + indicates higher value as a percentage.

Table 6. Outcomes of comparative analysis

\begin{tabular}{|c|c|c|}
\hline & Female & Male \\
\hline \multicolumn{3}{|l|}{ MICRO-FACTORS } \\
\hline \multicolumn{3}{|c|}{ Qualities and preconditions to become a successful entrepreneur } \\
\hline Business network & & + \\
\hline \multicolumn{3}{|c|}{ Most important factors discouraging to start a business } \\
\hline Lack of knowledge and skills & + & \\
\hline \multicolumn{3}{|l|}{ MACRO-FACTORS } \\
\hline \multicolumn{3}{|c|}{ Most problematic factors for doing business in a country } \\
\hline Inappropriately educated workforce & + & \\
\hline Lack of ethic in national labor force & & + \\
\hline \multicolumn{3}{|c|}{ MACRO FACTORS THAT COULD BE ENABLED BY ENTREPREURIAL EDUCATION } \\
\hline \multicolumn{3}{|c|}{ Skills needed to start a business } \\
\hline Sales and marketing skills & & + \\
\hline Financial management skills & + & \\
\hline Specific professional skills related to industry specifics & & + \\
\hline
\end{tabular}

Source: Authors' calculations

The analysis of differences between the two groups and their statistical significance guides to critical discussion involving and comparing arguments and outcomes from other researches made before, statistics and relevant literature. 


\section{Discussion}

The empirical study has provided insight results on the importance of different macro and micro factors believed to be important in starting a business by Latvian students with an extensive emphasis on gender differences. Following the research model based on the literature review, the different factors that influence entrepreneurial intentions were grouped into micro and macro factors (including education and training). After analyzing the survey, differences between groups observed were quite significant. Several statistically significant differences worth discussing were detected between Latvian male and female students.

The vision about future career choices shows statistically significant difference depending on gender. Male students are much more inclined to developing and managing their own business than female students. This fully corresponds to the reality observed for many years by Global Entrepreneurship Monitor consortium. Thus, in year 2019 there was a 19.6\% Total early-stage Entrepreneurial Activity (TEA) rate for male in Latvia, while female rate stood at $11.3 \%$ (GEM, 2020). Both rates are very high in the EU context, however the gender difference is worth noting too.

There is a 1 difference in the self-assessment regarding possession of skills to start a business. Male students have much higher belief in their skills to start a business. At the same time, it should be emphasized that survey data reflect only subjective views and perceptions of respondents and not proven facts about possession of skills in reality. The phenomena of higher self-esteem in male population has been discussed in this paper's literature review referring to Shirokova et al. (2016) and Vamvaka et al. (2020).

One of the most significant differences was found regarding most important factors that discourage starting a business, where female reveal a lack of knowledge and skills. It has been discussed by several authors (Haus et al., 2013; Camelo-Ordaz et al., 2016) that females transform their entrepreneurial intentions into action much less than males, because females tend to perceive various obstacles to entrepreneurship in a more tangible way. It has also been found that the fear of failure is one the most important obstacles for female students to start a business.

When analyzing the most problematic factors for doing business in a country, the perception about an inappropriately educated workforce is higher in females than in males. It is again related to the higher requirements put forward and lower self-esteem in female population discussed by authors mentioned in the previous paragraphs. The lack of ethics in national labor force appears as significant and higher in male students.

Problems with human capital quality arise concerns. Several studies made by many researchers emphasize that youths' success in the transition to entrepreneurship is closely related to the human capital element, which is very important to the entrepreneur's capability in maintaining business continuity, such as experiences of being involved in similar industry and business sector (Gartner, Starr, \& Bhat, 1999; Englis, Ratinho, Englis \& Harms, 2010; Mishra, 2005; Boyer \& Blazy, 2014), and formal education graduate (Dencker, Guber, \& Shah, 2009; Mishra, 2005).

Surveyed Latvians stress the inefficient government bureaucracy, tax rates and regulation as the most important obstacles to start their ventures than in other Eastern European countries.

Surveyed Latvian female students underline a significant difference in the ability to start a business, emphasizing the lack of financial management skills. Several authors believe females have lower level of financial literacy and gap in financial decision-making and also that females are less exposed to risk and usually avoid borrowing, equity crowdfunding and raising angel or venture capital, which discourage them to start a business (Al-Bahrani et al., 2020; Malaga et al., 2019). 
When analyzing some negative perceptions revealed from survey regarding entrepreneurial intensions, business environment and self-esteem, there is some controversy with the reality as proved by studies made by other institutions. For example, from year-toyear Latvia possesses very high position in World Bank's Doing Business index. Thus, for the year 2020, Latvia holds the $19^{\text {th }}$ position among 190 economies in the world in the Doing Business 2020 index. Looking at the scores for selected components, one can find that Latvia was placed $16^{\text {th }}$ in "Paying taxes", 26 ${ }^{\text {th }}$ in "Starting a business", $25^{\text {th }}$ in "Registering property", $15^{\text {th }}$ in "Getting credit" and $28^{\text {th }}$ in "Trading across borders" (World Bank, 2020). These scores placed Latvia well above most of the other Eastern European countries. This allows to conclude that the perceptions of students regarding bureaucracy, regulation and tax regimes do not match the reality and are rather related to some stereotypes surrounding the society in general regarding the business environment in the country.

\section{Conclusion}

This research highlights a set of results about entrepreneurial perceptions and aspirations of the Latvian students and their vision about their professional careers respectively. The impact of macro-factors, micro-factors and entrepreneurial education was analyzed in Latvia paying particular attention to gender issues.

In general, females see themselves working for private or public organization as specialists or managers, and just minority desires to develop or manage their own business. Males reveal an inverse result, most of them desire to become entrepreneurs. When analyzing perceptions about the skills required to start a business, the differences between genders are smaller, nevertheless males seem more confident than females.

Contemporary researches reveal that gender has a much higher influence on entrepreneurial intention than age and the student's specialty.

The results reveal several statistically significant differences between Latvian male and female students. Female students are more exposed to fear of failure and lower selfesteem regarding several skills and indirectly indicate lower belief in the quality of their business ideas. Males have higher belief in their skills to start a business, but reveal some macro constrains about ethic and values to develop a business. However, they require more skills in the field of marketing and specific industry knowledge to start a business. Females find great reveal a higher concern about their financial management skills.

Further research should include data from other countries to enlarge comparisons in order to identify eventual similarities and differences and new avenues for the study of the entrepreneurial education, particularly analyzing the gender differences and the role of higher education in this context.

\section{Acknowledgement}

The authors acknowledge to KABADA - Erasmus+ KA2 Knowledge Alliances program (project number: 612542-EPP-1-2019-1-LV-EPPKA2-KA). The first and fourth authors acknowledge to Fundação para a Ciência e Tecnologia (Grant number: UIDB/04007/2020). 


\section{References}

Adomssent, M, Fischer, D., Godemann, J., Herzig, C., Otte, I., Rieckmann, M., \& Timm, J., (2014) Emerging areas in research on higher education for sustainable development management education, sustainable consumption and perspectives from Central and Eastern Europe. Journal of Cleaner Production, 62, 17. doi: 10.1016/j.jclepro.2013.09.045

Al-Bahrani, A., Buser, W., \& Patel, D. (2020) Early Causes of Financial Disquiet and the Gender Gap in Financial Literacy: Evidence from College Students in the Southeastern United States. Journal of Family and Economic Issues 41, 558-571. https://doi.org/10.1007/s10834-020-09670-3

Ajzen, I. (1985). From intentions to actions: A theory of planned behavior. In J. Kuhl \& J. Beckman (Eds.), Action-control: From cognition to behavior (11-39). Heidelberg: Springer.

Ajzen, I. (1987). Attitudes, traits, and actions: Dispositional prediction of behavior in personality and social psychology. Advances in experimental social psychology, 20, 163. https://doi.org/10.1016/S0065-2601(08)60411-6

Ajzen, I. (2001). Nature and operation of attitudes. Annual Review of Psychology, 52, 27-58. https://doi.org/10.1146/annurev.psych.52.1.27

Ajzen, I. (2002). Perceived behavioral control, self-efficacy, locus of control, and the theory of planned behavior. Journal of Applied Social Psychology, 32(4), 665683. https://doi.org/10.1111/j.1559-1816.2002.tb00236.x.

Ajzen, I. (2011). The theory of planned behavior: Reactions and reflections. Psychology \& Health, 26(9), 1113-1127. https://doi.org/10.1080/08870446.2011.613995.

Ashcraft, C., McLain, B., Eger, E. (2016). Women in Tech: the Facts 2016 update. See what's changed and what hasn't. National Center for Women \& Information Technology (NCWIT). https://www.ncwit.org/sites/default/files/resources/ncwit_women-in-it_2016full-report_final-web06012016.pdf

Astebro, T., H. Herz, R. Nanda, \& R.A. Weber. (2014). Seeking the roots of entrepreneurship: Insights from behavioral economics. Journal of Economic Perspectives, 28(3), 49-70. doi: $10.1257 /$ jep. 28.3 .49

Atitsogbe, K. A., Mama, N. P., Sovet, L., Pari, P., \& Rossier, J. (2019). Perceived Employability and Entrepreneurial Intentions Across University Students and Job Seekers in Togo: The Effect of Career Adaptability and Self-Efficacy. Frontiers in psychology, 10, 180. https://doi.org/10.3389/fpsyg.2019.00180

Audretsch, D.B., \& Thurik, A.R. (2004). A Model of the Entrepreneurial Economy, International Journal of Entrepreneurship Education, 2, 143-166. doi: 10.12691/jbms4-4-2.

Audretsch, D.B., Thurik, A.R. (2010). Unraveling the Shift to the Entrepreneurial Economy, Tinbergen Institute Discussion Paper TI 2010-080/3, Rotterdam: Tinbergen Institute.

Bandera, C., Collins, R., \& Passerini, K. (2018). Risky business: Experiential learning, information and communications technology, and risk-taking attitudes in entrepreneurship education. The International Journal of Management Education, $16(2), 224-238$.

Bandura, A. (1977). Self-efficacy: toward a unifying theory of behavioral change. Psychological review, 84(2), 191-215. Doi: 10.1037/0033-295X .84.2.

Baumol, W.J. (1990). Entrepreneurship: Productive, Unproductive, and Destructive. Journal of Political Economy, 98(5, Part 1), 893-921. 
Baumol, W. J. (1993). Formal entrepreneurship theory in economics: Existence and bounds. Journal of Business Venturing, 8, 197-210. https://doi.org/10.1016/08839026(93)90027-3

Bengtsson, O., \& D. Ekeblom. (2014). The Bright but Right View? A New Type of Evidence on Entrepreneurial Optimism. IFN Working Paper No. 1008.

Bikse V., Riemere I., \& Rivza B. (2014), The Improvement of Entrepreneurship Education Management in Latvia, Procedia - Social and Behavioural Sciences, 140.

Bikse, V., Lusena-Ezera, I., \& Rivza, B. (2016). Performance trends in youth entrepreneur's capacity prerequisite for the entrepreneurship development of Latvia. Polish Journal of Management Studies, 14.

Blustein D., Masdonati J., \& Rossier J. (2017). Psychology and the International Labor Organization: The Role of Psychology in the Decent Work Agenda. Geneva, Switzerland:

ILO. http://www.ilo.org/global/research/publications/WCMS_561013/lang-en/index.htm

Camelo-Ordaz, C., Diánez-González, J., \& Ruiz-Navarro, J. (2016) The influence of gender on entrepreneurial intention: The mediating role of perceptual factors. BRQ Business Research Quarterly, 19, 261-277.

Carvalho, L., Costa, T. and Mares, P. (2015) 'A success story in a partnership programme for entrepreneurship education: outlook of students perceptions towards entrepreneurship', Int. J. Management in Education, 9(4), 444-465, doi: http://dx.doi.org/10.1504/IJMIE.2015.072097

Çera, G., Belas, J., Rozsa, Z., \& Cepel, M. (2019). Linking firm characteristics to perceived important social factors for entrepreneurial activity. Economics and Sociology, 12(4), 101-115, doi: 10.14254/2071- 789X.2019/12-4/6.

Chatterji, A., Glaeser, E.L., \& Kerr, W.R. (2014). Clusters of entrepreneurship and innovation. In J. Lerner \& S. Stern (Eds.) Innovation Policy and the Economy, 14. University of Chicago Press, Chicago, IL, 129-166

Chen, C.C., P.G. Greene \& A. Crick. (1998). Does entrepreneurial self-efficacy distinguish entrepreneurs from managers? Journal of Business Venturing, 13, 295-316.

Cheung, C-K. (2008) 'Entrepreneurship education in Hong Kong's secondary curriculum: possibilities and limitations', Education + Training, 50(6), 500-515. Doi:10.1108/ 00400910810901827.

Davey, T., Plewa, C. \& Struwig, M. (2011), "Entrepreneurship perceptions and career intentions of international students", Education $\quad+$ Training, 53(5), 335352. doi:10.1108/00400911111147677.

Dencker, J. C., Gruber M., \& Shah, S. K. (2009). Pre-Entry Knowledge, Learning, and the Survival of New Firms. Organization Science, 20(3), 516-537. doi: 10.1287/orsc. 1080.0387.

Díez-Echavarría, L., Valencia-Arias, A., \& Bermúdez-Hernández, J. (2020). Tool for Measuring the Influence of the Field of Knowledge on Entrepreneurial Intention among University Students". Periodica Polytechnica Social and Management Sciences, 28(1), 38-47. doi: 10.3311/PPso.12873

Draskovic, V., Popov, E., \& Peleckis, K.K. (2017). Modelling of Institutional Changes in Transition Countries - the Gap Between the Theory and Practice. Montenegrin Journal of Economics, Vol. 13, No. 1, 125-140.

Duffy R. D., Blustein D. L., Diemer M. A., \& Autin K. L. (2016). The psychology of working theory. J. Couns. Psychol. 63 127-148. doi:10.1037/cou0000140 
Dzene, O., \& Sennikova, I. ( 2020) Women's representation on corporate boards at the global and European level, Journal of Business Management Vol. 18, 2020, pp. 6-25. doi:10.32025/RIS18049

Eizaguirre, A., Díaz-Iso, A., Vivar-Simón, M., \& Markuerkiaga, L. (2020). An analysis of the Spanish universities' entrepreneurial activities through secondary data (websites and reports). Journal of Entrepreneurship Education, 23(4).

Englis, P. D., Ratinho, T., Englis, B. G., \& Harms, R. (2010). Extensiveness of Business Planning and Firm Survival: an Examination into the Drivers of Success and Survival for Knowledge Intensive Start-up Firms (Interactive paper). Frontiers of Entrepreneurship Research, 30(12), Article 20. Retrieved from http://digitalknowledge.babson.edu/fer/vol30/iss12/20/.

Eyel, C. Ş., Kaplan, B., \& Ünkaya, G. (2020). The effect of business administration students' individual values on their entrepreneurial tendency in Istanbul. Economics and Sociology, 13(4), 187-212. doi:10.14254/2071-789X.2020/13-4/12

Fiet, J. O. (2014). The relationship between entrepreneurship education and entrepreneurial intentions: A meta-analytic review. Entrepreneurship Theory \& Practice, 38(2), 217254. https://doi.org/10.1111/etap.12095

Forsythe A. (2017). I doubt very seriously whether anyone will hire me; factors predicting employability perceptions in higher education. Cogent Psychology, 4, 1-13. Doi: 10.1080/23311908.2017.1385131

Fox, A., Iriste' S., \& Bezeljak, P. (2019) Detecting a Sustainable Mindset through Using Content Analysis of Teacher-produced Learning Journals, Journal of Teacher Education for Sustainability, 21 (1), 35-47, 2019, doi: 10.2478/jtes-2019-0003

Gaglio, C. M., \& Katz, J. A. (2001). The psychological basis of opportunity identification: Entrepreneurial alertness. Small Business Economics, 16,95-111. Doi: 10.1023/A:1011132102464

Gartner, W. B., Starr, J., \& Bhat, S. (1999). Predicting new venture survival: an analysis of "anatomy of a start-up." Cases from inc. Magazine. Journal of Business Venturing, 14(2), 215-232. doi: 10.1016/S0883-9026(97)00063-3.

Global Entrepreneurship Monitor (2020), 2019/2020 Global Report, Global Entrepreneurship Research Association, London Business School, Regents Park, London NW1 4SA, UK, ISBN: 978-1-9160178-3-2

Gupta, V.K., Turban, D.B., Wasti, S.A., \& Sidkar, A. (2009). The role of gender stereotypes in perceptions of entrepreneurs and intentions to become an entrepreneur. Entrepreneurship Theory and Practice, 33(2), 397-417.

Hattab, H.W. (2014). Impact of entrepreneurship education on entrepreneurial intentions of university students in Egypt. The Journal of Entrepreneurship, 23(1), 1-18. https://doi.org/10.1177/0971355713513346

Haus, I., Steinmetz, H., Isidor, R., \& Kabst, R. (2013). Gender effects on entrepreneurial intention: a metanalytical structural equation model. International Journal of Gender and Entrepreneurship, 5(2), 130-156.

Hofstede, G. (1998). Masculinity/femininity as a dimension of culture. In Hofstede, G. (Ed.), Masculinity and femininity: The taboo dimension of national cultures, 3-28. Thousand Oaks, CA: Sage.

Hurst, E., \& Pugsley, B.W. (2016). Wealth, tastes, and entrepreneurial choice. In J. Haltiwanger, E. Hurst, J. Miranda \& A. Schoar (Eds.) Measuring Entrepreneurial Businesses: Current Knowledge and Challenges. University of Chicago Press, Chicago, IL. 
Iakovleva, T. Kolvereid, L. \& Stephan, U. (2011) 'Entrepreneurial intentions in developing and developed countries', Education + Training, 53(5), 353-370. Doi: $10.1108 / 00400911111147686$

Jones, C. and English, J. (2004) 'A contemporary approach to entrepreneurship education', Education + Training, 46 (8/9), 416-423. Doi: 10.1108/00400910410569533

Kamberidou, I., Pascall, N. (2019)The Digital Skills Crisis: Engendering TechnologyEmpowering Women in Cyberspace. European Journal of Social Sciences Studies, [S.L.], Dec. 2019. doi:Http://Dx.Doi.Org/10.46827/Ejsss.V0i0.683

Kamberidou, I. (2020). "Distinguished" women entrepreneurs in the digital economy and the multitasking whirlpool. Journal of Innovation and Entrepreneurship, Springer Open, 9(3), 1-26. Springer Nature. https://doi.org/10.1186/s13731-020-0114-y

Kasler J., Zysberg L., Harel N. (2017). Hopes for the future: demographic and personal resources associated with self-perceived employability and actual employment among senior year students. J. Educ. Work, 30, 881-892. Doi: 10.1080/13639080.2017.1352083

Keller, P. G. (2017). Opportunities and Obstacles for Information Technology Start-Ups in Europe: A Comparison between Germany and Latvia. Journal of EU Research in Business, Vol. 2017 (2017), Article ID 422546, doi: 10.5171/2017.422546

Kerr, S., Kerr, W. and Xu, T. (2017) Personality Traits of Entrepreneurs: A Review of Recent Literature, Working Paper 18-047, Harvard Business School.

Kuratko, D.F. (2005). The Emergence of Entrepreneurship Education: Development, Trends, and Challenges. Entrepreneurship Theory \& Practice (September), 577-597. doi: 10.1111/j.1540- 6520.2005.00099.x.

Kozlinska, I., (2016) Evaluation of the outcomes of entrepreneurship education: revisited evidence from Estonia and Latvia, available on: http://hdl.handle.net/10062/54670

Lim, R. Lent, R. L.T. Penn Prediction of job search intentions and behaviors: Testing the social cognitive model of career self-management. Journal of Counseling Psychology, 63, 594-603, doi: 10.1037/cou0000154

Liñán, F., \& Fayolle, A. (2015) systematic literature review on entrepreneurial intentions: Citation, thematic analyses, and research agenda. International Entrepreneruship Management. Journal. 11, 907-933.

Lent R. W., Ireland G. W., Penn L. T., Morris T. R., \& Sappington R. (2017). Sources of selfefficacy and outcome expectations for career exploration and decision-making: a test of the social cognitive model of career self-management. Journal of Vocational Behavior. 99, 107-117. Doi: 10.1016/j.jvb.2017.01.002

Malaga, R., Mamonov, S. \& Rosenblum, J. (2018), Gender difference in equity crowdfunding: an exploratory analysis, International Journal of Gender and Entrepreneurship, Vol. 10 No. 4, pp. 332-343. https://doi.org/10.1108/IJGE-03-20180020

Mavlutova, I., Lesinskis, K., Liogys, M., \& Hermanis, J. (2020) Innovative teaching techniques for entrepreneurship education in the era of digitalisation Wseas transactions on environment and development, 16, 2020, 725-733, doi: 10.37394/232015.2020.16.75

Markuerkiaga, L., Caiazza, R., Igartua, J.I., \& Errasti, N. (2016). Factors fostering students' spin-off firm formation: An empirical comparative study of universities from North and South Europe. Journal of Management Development, 35(6), 814-846.

Matlay, H., \& C. Carey. (2007). "Entrepreneurship Education in the UK: A Longitudinal Perspective." Journal of Small Business and Enterprise Development, 14, 252-263. 
Mishra, A. (2005). Entrepreneurial Motivations in Start-up and Survival of Micro- and Small Enterprises in the Rural Non-Farm Economy. Journal of Small Business and Entrepreneurship, 18(3), 289-326. doi: 10.1080/08276331.2005.10593345.

Neneh, B.N. (2020). Entrepreneurial self-efficacy and a student's predisposition to choose an entrepreneurial career path: the role of self-perceived employability, Education + Training, 62 (5), 559-580. doi: 10.1108/ET-06-2019-0108

Nikitina, T., Lapina, I. (2019) Creating and managing knowledge towards managerial competence development in contemporary business environment, Knowledge Management Research \& Practice, 17(1), 96-107, doi: 10.1080/14778238.2019.1569487

Nikitina, T., \& Lapina, I. (2017). Overview of trends and developments in business education Proceedings of the 21st World Multi-Conference on Systemics, Cybernetics and Informatics (WMSCI 2017) 2017/7/8, 2, 56-61.

Norman, W. T. (1963). Toward an adequate taxonomy of personality attributes: Replicated factor 54 structure in peer nomination personality ratings. Journal of Abnormal and Social Psychology, 66, 574-583. doi: 10.1037/h0040291

North, D. C. (1990). Institutions, institutional change, and economic performance. Cambridge University Press.

OECD (2017). Entrepreneurship at a Glance 2017; OECD Publishing: Paris, France.

Penaluna, K., A. Penaluna, \& C. Jones. (2012). "The Context of Enterprise Education: Insights into Current Practices." Industry \& Higher Education, 26, 163-175. Doi: 10.5367/ihe.2012.0098

Peterman, N.E. \& Kennedy, J. (2003). "Enterprise education: influencing students' perceptions of entrepreneurship", Entrepreneurship Theory and Practice, 28(2), 129-44.

Pinho, J. C. (2017). Institutional theory and global entrepreneurship: exploring differences between factor- versus innovation-driven countries. Journal of International Entrepreneurship, 15(1), 56-84. doi: 10.1007/s10843-016-0193-9.

Pittaway, L. \& Edwards, C. (2012) 'Assessment: examining practice in entrepreneurship education', Education + Training, 54(8), 778-800. Doi: 10.1108/00400911211274882

Ploum, L., Blok, V., Lans, T., \& Omta, O. (2018). Toward a validated competence framework for sustainable entrepreneurship. Organization and Environment, 31(2), 113-132. Doi: $10.1177 \% 2 \mathrm{~F} 1086026617697039$

Raza, A., Muffatto, M., \& Saeed, S. (2018). The influence of formal institutions on the relationship between entrepreneurial readiness and entrepreneurial behaviour. Journal of Small Business and Enterprise Development, 133-157. Doi: 10.1108/JSBED-012018-0014

Rauch, A. (2014). Predictions of entrepreneurial behavior: A personality approach. In E. Chell \& M. Karatas-Ozkan (Eds.) Handbook of Research on Small Business and Entrepreneurship. Edward Elgar, London, UK, 165-183.

Rahmatiah, Wiroto, D. W., \& Taan, H. (2019). Business continuity, motivation, and social conditions of young entrepreneurs. Economics and Sociology, 12(4), 166-182. doi: 10.14254/2071-789X. 2019/12-4/10.

Rahmatiah, Wiroto, D. W., \& Taan, H. (2017). A Conceptual Framework in the Formation of Young Entrepreneurs in Indonesia. Junal Ilmu Sosial dan Ilmu Politik, 21 (2). 102-116. doi:10.1007/s11187-007-9093-7

Rossier J. (2015). Career adaptability and life designing. In Handbook of Life Design: From Practice to Theory and From Theory to Practice, eds Nota L., Rossier J. (Göttingen: Hogrefe; ), 153-167. 
Roxas, B., Cayoca-Panizales, R., \& Mae de Jesus, R. (2008). Entrepreneurial knowledge and its effects on entrepreneurial intentions: Development of a conceptual framework. AsiaPacific Social Science Review, 8(2), 61-77

Rudolph C. W., Lavigne K. N., \& Zacher H. (2017). Career adaptability: a meta-analysis of relationships with measures of adaptivity, adapting responses, and adaptation results. $J$. Vocat. Behav. 98, 17-34. 10.1016/j.jvb.2016.09.002

Salīte, I. (2015). Searching for Sustainability in Teacher Education and Educational Research: Experiences from the Baltic and Black Sea Circle Consortium for educational research, Discourse and Communication for Sustainable Education, 6(1), 2129. Doi:10.1515/dcse-2015-0002

Savickas M. L., \& Porfeli E. J. (2012). Career adapt-abilities scale: construction, reliability, and measurement equivalence across 13 countries. J. Vocat. Behav. 80, 661-673. Doi:10.1016/j.jvb.2012.01.011

Shinnar, R., Giacomin,O., \& Janssen, F. ( 2012) Entrepreneurial Perceptions and Intentions: The Role of Gender and Culture. Entrepreneurship Theory and Practice. Vol 36, Issue 3, 2012, doi.org/10.1111/j.1540-6520.2012.00509.x

Shirokova, G., Osiyevskyy, O., \& Bogatyreva, K. (2016). Exploring the intention-behavior link in student entrepreneurship: Moderating effects of individual and environmental characteristics. European Management Journal, $34(4), \quad 386-399$. doi: 10.1016/j.emj.2015.12.007.

Sinapi, C., Ballereau, V., Toutain, O., \& Juno-Delgado, E. (2015). Developing a business model; The perception of entrepreneurial self-efficacy among students in the cultural and creative industry. In book: Creative Human Capital: Cultural Entrepreneurship in Theory, Pedagogy and Practice, Publisher: Delft: Eburon Academic Press, Editors: A. Schramme, R. Kooyman, O. Kuhlke, pp.164-177.

Sobel, R. S. (2008). Testing Baumol: Institutional quality and the productivity of entrepreneurship. Journal of Business Venturing, 23(6), 641-655.

Toutain, O., \& Alain, F. (2017) Labour Market Uncertainty and Career Perspectives: Competence in Entrepreneurship Courses, In book: Competence-based Vocational and Professional Education, doi: 10.1007/978-3-319-41713-4_46.

Tupes, E. C., \& Christal, R. C. (1961). Recurrent personality factors based on trait ratings. Technical Report, USAF, Lackland Air Force Base, TX.

Tupes, E. C., \& Christal, R. C. (1992). Recurrent personality factors based on trait ratings. Journal of Personality, 60, 225-251. doi: 10.1111/j.1467-6494.1992.tb00973.x

Vamvaka, V., Stoforos, C., \& Palaskas, T. (2020) Attitude toward entrepreneurship, perceived behavioral control, and entrepreneurial intention: dimensionality, structural relationships, and gender differences. Journal of Innovation and Entrepreneurship, 5, doi: 10.1186/s13731-020-0112-0

Vodă, AI, \& Florea, N. (2019) Impact of Personality Traits and Entrepreneurship Education on Entrepreneurial Intentions of Business and Engineering Students. Sustainability. 11(4), 1192. doi.org/10.3390/su11041192

World Bank Group (2019) Doing Business 2020, Economy Profile Latvia, World Bank Group

Wilson, F., Kickul, J., \& Marlino, D. (2007). Gender, entrepreneurial self-efficacy, and entrepreneurial career intentions: Implications for entrepreneurship education. Entrepreneurship Theory and Practice, 31(3), 387-406.

Yen, W.C., \& Lin, H.H. (2020). Investigating the effect of flow experience on learning performance and entrepreneurial self-efficacy in a business simulation systems context. Interactive Learning Environments, 1(2), 1016. 
Zajkowski, R., \& Domańska, A. (2019). Differences in perception of regional proentrepreneurial policy: does obtaining support change a prospect? Oeconomia Copernicana, 10(2), 359-384. Doi: 10.24136/oc.2019.018

Zinovyev, A. (1986). Homo Sovieticus, New York: Grove/Atlantic. 